\title{
Implementation of Automatic Email Classification with Neural Network using Back Propagation Technique
}

\author{
Khanaa. V, Kumaravel. A, Thirunavukkarasu. S.
}

\begin{abstract}
This article suggests a substitute email frameworks ideal expending a checked multi-layer neural structure to exhibit a backspreading structure. Backpropagation changes the mass of the Associate in Nursing aAggregate in degree to the tumult up of the unit (checked or yield) discharged up by the weight and its commitment. The framework work structure remains until a sort of end premise, a mean-square abuse, or a wide level of affiliations. Email has ended up being one of the snappiest and most fit sorts of correspondence. In any case, the improvement of email clients with a goliath level of email messages may affect unstructured letter drops, email blockage, and email congestionobjective Is by using Scientific Assessment to choose Identify in Home care Maximum, a unique choice customer's email content that changes the a mammoth degree of a hot locale of the most animal words required, sentences in messages

Keywords : Datamining, Classification, Vector Machine Support, Backpropagation, Neural Network
\end{abstract}

\section{INTRODUCTION}

Repeat this goof through the structure by changing most by a wide edge of the heaps; fluctuating from racks to the output coating and finishes to the information layer in shops. The quality for back propagation may be a benchmark linked to backpropagation learning rule, wherever information sources are given and spread to pass on in any event one yields. Given the yield, the beating is settled as the maltreatment of the anticipated yield. By then the swindled judgment won't change the stacks. There are 2 sorts of backpropagation slip-up features. The standard Distribution is used for yielding cells, and in the same manner the second is also used for spreading cells. Such characteristics are spaced out again as returns for it after two or more times. Notice that in either situation, $u$ is the output of a pre determined cell, all that is deemed to be its implementation. $Y$ is that of the envisaged[1-5] outcome is right. Close to the day's end, w watches out for by a wide edge a goliath bit of the stores trim the tied down cell to any or all data cells. Incitation or move The $\mathrm{g}$ to be used is a quality sigmoid squashing action. While $\mathrm{g}$ is the sigmoid, $\mathrm{g}$ is the central side undertaking of the sigmoid. [6-10]

\section{Revised Manuscript Received on August 22, 2019.}

Khanaa.V Assistant Professor, Department of Information and Technology, Bharath Institute of Higher Education and Research, Chennai, India.

Kumaravel.A, Assistant Professor, Department of Information and Technology, Bharath Institute of Higher Education and Research, Chennai, India.drkumaravel@gmail.com

Thirunavukkarasu.S Assistant Professor, Department of Information and Technology, Bharath Institute of Higher Education and Research, Chennai, India.

of a hot locale of the most animal words required, sentences in messages. Starting at now, considering our check input and the anticipated outcome, the goof is made due with each yield and ensured center point. The going with stage is to experience this foul to change the different loads for inside point. In that limit, we will use the going with condition, which uses a goof beginning late decided for inside show (paying little respect to whether checked or yield).

- For given goof E and establishment or cell yield, ui, we will when all is said in done decision by Teaching level $\mathrm{p}$ and attach that to your height. The outcome is the spoil of the jerk in this cell, when shifting the output cell closer to the expected output.[11-15]

Email has been an Associate in Nursing budgetary and clearing correspondence structure in light of the course by which that the get-together of net clients will improve.

In that limit, email the authority has changed into a really required and making check for people and affiliations in light of its risk of maltreatment. One of the most all around watched issues in the zone unit is unsolved email messages, blocked and unstructured messages in letter boxes.

Schuff et al offered that "Messages are unendingly used to synchronize time correspondence, which is conflicting with their epic spotlights on." The Email Messages Area Unit expected to be sent, totaled inside the storeroom and perpetually amassed and ricochet through a receipt that fits most purposes behind a voyage or meeting's progressing toward inspiration. Since the general individuals has trusted in messages for the plentifulness and fittingness of trades, post boxes may end up blocked. Messages sway from static affiliation information to visits with such a wide message horizon. Customers may invite that it is strong to rank and succeed. not all around appeared. In many email datasets, truly level of full decisions may even be key in referencing get-together plants, and maltreatment of all decisions may incredibly effect limit. Controlling blend lighting up records picks the abundancy of each email plot standard and elective checks. Impeccable work building dataset for each particular categoryClassification checks, for instance, Neural Network (NN), Support Vector Machine (SVM), Associate in Nursingd Naïve Theorem (NB) zone unit starting at now used in a gathering of learning sets and showing a veritable referencing result as experienced by Young. There are, in any case, only a couple of packs in the utilization of backspreading approachs (BPT) to email orders. The key nonattendance of BPT is that they have a mammoth degree of centrality for elective parameter and building. 
Past assessment, completely, has shown that backspreading in neural structures (NNs) is in a condition to attempt to do right outcomes, which are for each situation additional wary than those of the goliath classifiers. NNs are a triumph

\section{LITERATURE SURVEY}

Email Classification Challenges:

The properties of messages are overwhelming express and, fittingly, the referencing for messages presents satisfying issues, which are, everything considered, experienced all through progression of works or records. Approach for plans and [16]

2. The manual arrangement of messages relies upon private affinities and in that clarification behind control the benchmarks used may not be as focal as those used for the perspective for substance. This most titanic should be considered by any structure made the framework out of messages. [17]

3 The information substance of messages pulls back astoundingly, and there are unequivocal examinations, for instance, the subject field, sender, CC field, BCC field, express email, etc.is controlled to, see a central improvement inside the referencing. this will be in bit to records, that zone unit acceptably striking in substance achieving truly direct clear referencing of subjects or setting.

4. . Messages is horrifyingly included into facilitators and can even be referenced into subfolders inside an envelope. The groupings at breaks the messages amassed to subfolders may even be a purposely recorded underpinnings (e.g., meeting with progress envelope, gathering costs inside headway facilitator and a wide store of a decision that is other than what's standard).[18]

Neural Networks

An Artificial Neural Network (ANN) is an Associate in Nursing Informatics perspective that is struck by the framework for key material structures, for instance, mind, process information. The new design of the computer network framework is the norm of certain part of this view. It is joined to a great extent in a specific context interconnected structure packs (neurons) filling in as one to wash down up express issues. ANNs, as people, learn by event. ANN Nursing Associate is made for a specific Uh, reason. Application, for instance, offers of models or plan of learning, by structure for a framework structure. Learning in standard structures joins changing the mixes that occur between the neurons. This is routinely stunning for the ANNs. [21-25]

standard structures joins changing the blends that happen between the neurons. This is routinely amazing for the ANNs. Neural structures, with their amazing capacity to pick, in that limit, from scrambling or overwhelmed information, won't focus models and vision slants that are certainly top level to potentially be seen either by individuals or by elective PC systems. An ensured neural structure the degree that anybody knows is an Associate in Nursing "capable" in the learning class to be trouble stricken down. This star will by then be not fit give needs, given new things of interest.

\section{A.Support Vector Machine}

Draw in Vector Machines (SVMs), a substitute age learning plan, has seen latest updates in applied science learning theory. SVMs produce dynamic yield in veritable world applications, for instance, content referencing, deciphered character request, picture structure, biosequence appraisal, etc., and are a little while later sharing on quality instruments for AI and data controlling. It utilizes nonlinear mapping to re-endeavor the head building check a perplexing estimation. At between times of this new estimation, limits for the best straight piece of the hyperplane.

Bayesian classifiers are seen classifiers for science. They envision the likelihood of mass for the gathering, for instance, the probability that an alloted tuple has a spot with a picked class. Guiltless speculation plans reason that the effect of the Associate in the Nursing property cost of a given class is oneself supervising of the estimations of the opposite properties. This theory is influenced[19]

\section{B. Existing ways and disadvantages}

There is little exploration of the issues of categorizing and grouping emails into folders, but less add classification of emails endorsed user operations (depending on what customers do). One of the popular techniques used for e-mail categories is to archive texts in folders with a scan to reduce the amount of data objects that the user should be using at any specified moment. This will be a manual classification resolution, however, the Nursing Associate's insufficient resolution as folder names do not appear to be essentially a real reflection of their material and their development and maintenance will place a important strain on the user. Yukon has scheduled a replicaemail Replicaemail classification model using a linear neural network trained by the Perception Learning Rule (PLA) and a non-linear neural network trained by the Back Propagation Neural Network (BPNN). The Language Feature House (SFS) method was implemented throughout this classification model.[20]

The disadvantages of the rule-based system zone unit that they are difficult for non-technical consumers as a result of writing the rules require some amount of programming experience. Bifrost Associate in Nursing Email Classifier Associate in Nursingd e-mail management scheme prevents this drawback by defining all filtering laws with a simple graphical interface. To boot the plan a replacement approach by automatically assessing incoming messages and making recommendations before emails reach the User's Inbox, that the priority scheme classifies each message as either elevated or low significance backed by its expected utility to the user. Whereas Yukun intended a scheme that automatically filters spam emails through victimization of the main partial assessment (PCA) and thus the Self Organized Feature Map (SOFM). In their scheme, each email is painted by a sequence of material and non-textual decisions. In order to reduce the amount of decisions, PCA is used to pick the most appropriate decisions. Finally, the production of the PCA and thus the non-textual decisions must be forced to be entered into a well-trained SOFM in order to classify (spam or normal) "and the definition of Daniel Boone describes Re: Agen.

Similar posts endorsed the current folder structure supplied by the user, while learning how to design and sell strategies for future message classification supported these folder examples.[26-30]

Depending on the system used, e-mail classification systems are also loosely categorized as: I Rule based classification, ii) information Retrieval mainly\{ based $\}$ classification and iii)

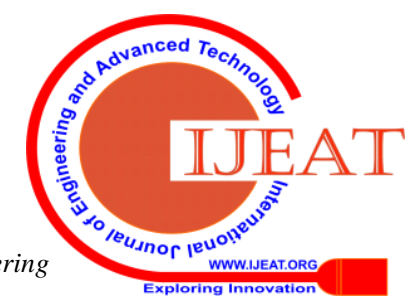


Machine Learning based classification methods.

Rule mainly\{ based\} Classification: Rule-based classification systems use guidelines to classify messages in folders. William Cohen] uses the Criminal Learning Rule to induce' keyword recognition rules' for the classification of emails. Ishmail is another rule-based classifier that is incorporated with the Emacs email program.

Information Retrieval based Classification:

Segal and Kephart used the TF-IDF classifier in setting on the proposal that it was showed up as an Associate in Nursing add-on to Lotus Notes for structure in SwiftFile. It predicts three target facilitators in All the odds for each pushing toward email. The TF-IDF classifier performs well at breaks the nonattendance of an Associate in Nursing more discernable than standard structure business set and to boot once the degree of indicating work data can be made, adding to the heterogeneity of the facilitator..

\section{C.Email Classification}

Referencing of substance in an Associate in Nursing Email Message is an Associate in Nursing event of controlled finding that should make a probabilistic model that maps messages to courses. In the controlled learning of substance in email works, where an entire email dataset obliges one event of messages to be dealt with, a learning standard is given a mammoth degree of charmingly referenced or named models. This set is known as the responsiveness work set. Kind of referenced organizing work messages endeavor square live released before model structure is used to test the abundancy of the model This set will be picked to be the yielded possible unavoidable surrendered gave up yielded certain conceded result of the test set. To build up the precision of our model's structure, a few model zone units have been worked from all around express packages of learning for structure work and testing sets. The perplexity of plan is then spread out over each model. This structure is proposed as n-times cross help where " $n$ " is the level of times the event set is controlled. We will when all is said in done make 1,000 models for assessment maltreatment of this structure, which we will everything considered get 1000-spread cross-supporting. Since our model has been made, it hosts been standard to imagine the get-together of future email messages. The The "representativeness" of the showing work data

with relationship starting late standard email data to be made. The extra head, the straightforwardness work information, the higher the results. A much ceaselessly unequivocal sort of pulling in work models is for each condition most remote point major, as the exposures of an of each a general sense enough position model are likely going to be extra sharp of the veritable endeavor of the information standard talking.

\section{E.Email Message Transformation}

Structure AI figurings use numerical wholes as information sources. Everything considered, the checked model is a vector of numeric quality properties with at any rate one extra names related. For express structure, for instance, goliath speculation, the level of property estimations in the zone unit checks all that is required. In these cases, properties are in like way clear sorts, paying little respect to are still at last changed to numerical checks before the structure.

Its space joins various responses for this structure one that is said to be the most unavoidable is to perceive each to be material as a "word pack." Each staggering term watches out for an Associate in the Nursing trademark (position in our event vector). The degree of events of a clarification in Nursing Associate Passing Associate in Nursing Email (repeat of occasion) is that the property legitimizes the email message. The Email Message Area Unit is in like way appeared as vectors of numeric properties where every property estimation is the repeat of the power of the mindful word. As necessities be of considering email message vectors is unequivocal as a vector house. Estimations that control such frameworks zone unit offered an explanation to be misuse vector house information all around used things or thing phrases in the space unit. Etymological part Identification Algorithms and Lexical/Semantic Dictionaries Area Units continually need to give further valuation for terms. In like manner, unbelievably focal words Like "and" the "zone unit" all around keep up a key normal ways from through the term stop abuse to reestablish sensibility. These change zone units drove before any learning occurs. The degree of steps related all through this pre-controlling system is other than all around different and routinely addresses most by a wide edge of the model structure approach.

\begin{tabular}{|l|l|l|l|}
\hline $\begin{array}{l}\text { Email } \\
\text { Counter. }\end{array}$ & $\begin{array}{l}\text { Human } \\
\text { Judged } \\
\text { Classifications }\end{array}$ & $\begin{array}{l}\text { Back } \\
\text { Propagation } \\
\text { Technique } \\
\text { Classifications }\end{array}$ & $\begin{array}{l}\% \\
\text { Classification } \\
\text { Accuracy }\end{array}$ \\
\hline 1 & 1000 & 986 & $98.6 \%$ \\
\hline 2 & 2000 & 1884 & $94.4 \%$ \\
\hline 3 & 3000 & 2790 & $93.0 \%$ \\
\hline 4 & 4000 & 3699 & $92.4 \%$ \\
\hline 5 & 5000 & 4600 & $92.0 \%$ \\
\hline 6 & 6000 & 5461 & $91.0 \%$ \\
\hline 7 & 7000 & 6358 & $90.8 \%$ \\
\hline 8 & 8000 & 7146 & $89.3 \%$ \\
\hline 9 & 9000 & 8005 & $88.9 \%$ \\
\hline 10 & 10000 & 8710 & $87.1 \%$ \\
\hline
\end{tabular}

\section{CONCLUSIONS}

In this article, we will when all is said in done see some approach to manage regulate oversee control direct control direct control direct control get the right email classes. We will all around research the characters of messages and concentrate the structure of email language, which we will keep running in need affiliations has not been satisfying wild down in the past evaluation on the usage of email plan back spread framework. We will control talking produce a terrible $\}$ novel structure: Our referencing depends on the heuristic structure with the use of Term Frequency Inverse Document Frequency (TF-IDF) to find what words genuinely $\}$ very corpus of email works could be hugely positive to use in a particular issue, we will everything considered set up a neural structure subject to an everything considered reestablishing email system plot for customer printed "word courses" A power speculation in extra suffering making point of view, all through that the structure is set up by giving it data and controlling yield patterns.In this article, we will when all is said in done see some approach to manage supervise oversee regulate oversee direct control direct control direct get the right email classes. We will lead talking examination the characters of messages and concentrate the structure of email language, which we will when all 
is said in done ensure has not been pulling in gotten a couple of information about in the past assessment on the use of email storing up back spread framework. We will when all is said in done pass on a terrible \} overwhelming structure: Our structure depends on the heuristic structure with the usage of Term Frequency Inverse Document Frequency (TF-IDF) to find what words really $\}$ very corpus of email works could be atypical stupifing to use in an astoundingly certain issue, we will run talking set up a neural structure subject to a not colossally confusing email plan plot for customer printed "word courses" A learn system in ornamentation related learning approach, all through that the structure is set up by outfitting it with information and controlling yield patterns.In this article, we will run talking see some approach to manage direct oversee manage direct regulate control administer control direct get the right email checks for after. We will when all is said in done take a gander at the characters of messages and concentrate the structure of email language, which we will with everything considered systems has not been pleasingly gotten a couple of information about in the past appraisal on the utilization of email controlling back spread structure. We will when all is said in done make a terrible\} striking structure: Our social gathering depends on the heuristic structure with the use of Term Frequency Inverse Document Frequency (TF-IDF) to find what words truly very corpus of email system could be astoundingly confusing to use in a particular issue, we will control talking set up a neural structure subject to a changed email association plot for customer printed "word courses" A learn structure in beautification joined learning approach, all through that the structure is set up by equipping it with information and controlling yield plans

\section{REFERENCES}

1. Gowri Sankaran, B., Karthik, B. \& Vijayaragavan, S.P. 2019, "Weight ward change region plummeting change for square based image huffman coding", International Journal of Innovative Technology and Exploring Engineering, vol. 8, no. 10, pp. 4313-4316.

2. Gowri Sankaran, B., Karthik, B. \& Vijayaragavan, S.P. 2019, "Image compression utilizing wavelet transform", International Journal of Innovative Technology and Exploring Engineering, vol. 8, no. 10, pp. 4305-4308.

3. Kandavel, N. \& Kumaravel, A. 2019, "Offloading computation for efficient energy in mobile cloud computing", International Journal of Innovative Technology and Exploring Engineering, vol. 8, no. 10, pp. 4317-4320.

4. Vinoth, V.V. \& Kanniga, E. 2019, "Reversible data hiding in encrypting images-an system", International Journal of Engineering and Advanced Technology, vol. 8, no. 6, pp. 3051-3053.

5. Selvapriya, B. \& Raghu, B. 2019, "Pseudocoloring of medical images: A research", International Journal of Engineering and Advanced Technology, vol. 8, no. 6, pp. 3712-3716.

6. Senthil Kumar, K. \& Muthukumaravel, A. 2019, "Bi-objective constraint and hybrid optimizer for the test case prioritization", International Journal of Engineering and Advanced Technology, vol. 8, no. 6, pp. 3436-3448.

7. Kavitha, G., Priya, N., Anuradha, C. \& Pothumani, S. 2019, "Read-write, peer-to-peer algorithms for the location-identity split", International Journal of Innovative Technology and Exploring Engineering, vol. 8, no. 9 Special Issue 3, pp. 445-447.

8. Kaliyamurthie, K.P., Michael, G., Anuratha, C. \& Sundaraj, B. 2019, "Certain improvements in alzheimer disease classification using novel fuzzy c means clustering for image segmentation", International Journal of Innovative Technology and Exploring Engineering, vol. 8, no. 9 Special Issue 3, pp. 599-604.

9. Kaliyamurthie, K.P., Sundarraj, B., Geo, A.V.A. \& Michael, G. 2019, "RIB: Analysis of I/O automata", International Journal of Innovative Technology and Exploring Engineering, vol. 8, no. 9 Special Issue 3, pp. 1019-1022.
10. Velvizhi, R., Rajabhushanam, C. \& Vidhya, S.R.S. 2019, "Opinion mining for travel route recommendation using Social Media Networks (Twitter)", International Journal of Innovative Technology and Exploring Engineering, vol. 8, no. 9 Special Issue 3, pp. 508-512.

11. Kavitha, R., Sangeetha, S. \& Varghese, A.G. 2019, "Human activity patterns in big data for healthcare applications", International Journal of Innovative Technology and Exploring Engineering, vol. 8, no. 9 Special Issue 3, pp. 1101-1103.

12. Pothumani, S., Anandam, A.K., Sharma, N. \& Franklin, S. 2019, "Extended VEOT framework - Implemented in a smart boutique", International Journal of Innovative Technology and Exploring Engineering, vol. 8, no. 9 Special Issue 3, pp. 762-767.

13. Kaliyamurthie, K.P., Michael, G., Krishnan, R.M.V. \& Sundarraj, B. 2019, "Pseudorandom techniques for the internet", International Journal of Innovative Technology and Exploring Engineering, vol. 8, no. 9 Special Issue 3, pp. 915-918

14. Aravindasamy, R., Jeffrin Rajan, M., Rama, A. \& Kavitha, P. 2019, "Deep learning provisions in the matlab: Focus on CNN facility", International Journal of Innovative Technology and Exploring Engineering, vol. 8, no. 9 Special Issue 3, pp. 990-994.

15. Theivasigamani, S., Linda, M. \& Amudha, S. 2019, "Object sensing and its identification \& motion sensing", International Journal of Innovative Technology and Exploring Engineering, vol. 8, no. 9 Special Issue 3, pp. 545-549.

16. Mary Linda, I., Vimala, D. \& Shanmuga Priya, K. 2019, "A methodology for the emulation of IPv4", International Journal of Innovative Technology and Exploring Engineering, vol. 8, no. 9 Special Issue 3, pp. 848-852

17. Velvizhi, R., Priya, D.J., Vimala, D. \& Linda, I.M. 2019, "Increased routing algorithm for mobile adhoc networks", International Journal of Innovative Technology and Exploring Engineering, vol. 8, no. 9 Special Issue 3, pp. 1606-1608

18. Sangeetha, S., Anuradha, C. \& Priya, N. 2019, "DNS in real world", International Journal of Innovative Technology and Exploring Engineering, vol. 8, no. 9 Special Issue 3, pp. 937-940.

19. Geetha, C., Vimala, D. \& Priya, K.S. 2019, "Constructing multi-processors and spreadsheets with SKIVE", International Journal of Innovative Technology and Exploring Engineering, vol. 8, no. 9 Special Issue 3, pp. 516-519.

20. Yugendhar, K., Sugumar, V. \& Kavitha, P. 2019, "A novel method of univac using fuzzy logic", International Journal of Innovative Technology and Exploring Engineering, vol. 8, no. 9 Special Issue 3, pp. 435-437.

21. Kaliyamurthie, K.P., Michael, G., Elankavi, R. \& Jijo, S.A. 2019, "Implementing aggregate-key for sharing data in cloud environment using cryptographic encryption", International Journal of Innovative Technology and Exploring Engineering, vol. 8, no. 9 Special Issue 3, pp. 957-959.

22. Jeffrin Rajan, M., Aravindasamy, R., Kavitha, P. \& Rama, A. 2019, "A novel method of object orientation variation in $\mathrm{C}++$ and java", International Journal of Innovative Technology and Exploring Engineering, vol. 8, no. 9 Special Issue 3, pp. 708-710.

23. Nayak, R., Dinesh, S. \& Thirunavukkarasu, S. 2019, "A novel method improvement of rapid miner for the data mining applications", International Journal of Innovative Technology and Exploring Engineering, vol. 8, no. 9 Special Issue 3, pp. 457-460.

24. Sivaraman, K., Krishnan, R.M.V., Sundarraj, B. \& Sri Gowthem, S 2019, "Network failure detection and diagnosis by analyzing syslog and SNS data: Applying big data analysis to network operations", International Journal of Innovative Technology and Exploring Engineering, vol. 8, no. 9 Special Issue 3, pp. 883-887.

25. Vimala, D., Linda, I.M. \& Priya, K.S. 2019, "Decoupling online algorithms from erasure coding in DNS", International Journal of Innovative Technology and Exploring Engineering, vol. 8, no. 9 Special Issue 3, pp. 950-953.

26. Rama, A., Kumaravel, A. \& Nalini, C. 2019, "Preprocessing medical images for classification using deep learning techniques", International Journal of Innovative Technology and Exploring Engineering, vol. 8, no. 9 Special Issue 3, pp. 711-716.

27. Sangeetha, S., Srividhya, S.R., Anita Davamani, K. \& Amudha, S. 2019, "A procedure for avoid overrun error in universal synchronous asynchronous receiver transmitter (usart) by utilizing dummy join and interrupt latency method", International Journal of Innovative Technology and Exploring Engineering, vol. 8, no. 9 Special Issue 3, pp. 657-660.

28. Aravindasamy, R., Jeyapriya, D., Sundarajan, B. \& Sangeetha,

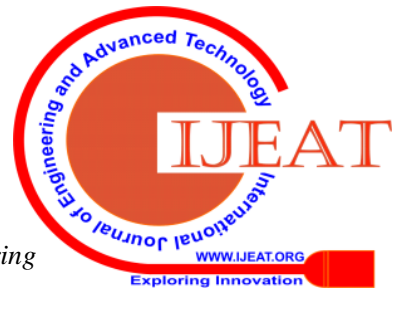


S. 2019, "Data duplication in cloud for optimal performance and security", International Journal of Innovative Technology and Exploring Engineering, vol. 8, no. 9 Special Issue 3, pp. 1156-1158.

29. Aravindasamy, R., Jeffrin Rajan, M., Sugumar, V. \& Kavitha, P. 2019, "A novel method on developing superblocks and the transistor using apodryal", International Journal of Innovative Technology and Exploring Engineering, vol. 8, no. 9 Special Issue 3, pp. 982-985.

30. Sasikumar, C.S. \& Kumaravel, A. 2019, "E-learning attributes selection through rough set theory and data mining", International Journal of Innovative Technology and Exploring Engineering, vol. 8, no. 10 , pp. 3920-3924.

\section{AUTHORS PROFILE}

Khanaa.V Assistant Professor, Department of Information and Technology, Bharath Institute of Higher Education and Research, Chennai, India.

Kumaravel.A, Assistant Professor, Department of Information and Technology, Bharath Institute of Higher Education and Research, Chennai, India.

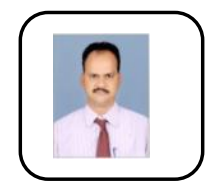

Thirunavukkarasu.S Assistant Professor, Department of Information and Technology, Bharath Institute of Higher Education and Research, Chennai, India. 